\title{
The effect of project based learning in "ratio, proportion and percentage" unit on mathematics success and attitude
}

\author{
Ahmet Şükrü Özdemir1, ${ }^{*}$, Filiz Yıldız ${ }^{2}$ and Sevda Göktepe Yıldız \\ 1,* Department of Elementary Mathematics Education, Marmara University, Istanbul, Turkey \\ 2 Bayrampasa Nail Resit Secondary School, Istanbul, Turkey \\ ${ }^{3}$ Department of Elementary Mathematics Education, Yildiz Technical University, Istanbul, Turkey \\ For correspondence: ahmet.ozdemir@marmara.edu.tr
}

\begin{abstract}
:
In this paper, our aim is to examine the effect of project based learning on $7^{\text {th }}$ grade students' mathematical success in "Ratio, Proportion and Percentage" unit and attitudes towards mathematics. This study was implemented with $707^{\text {th }}$ grade students of Atatürk Primary School in Eminönü District in Istanbul. Before starting the implementation, experiment and control groups were subjected to pre-test and mathematic behaviours scale. In the experiment group Project Based Learning was conducted whereas the control group was taught with traditional method. At the end of the study, both groups were subjected to final test and mathematic behaviours scale. Besides, the experiment group was given "Activity Evaluation Form", "Self Evaluation Form" and "Students Observation Form". Data obtained from the research were analyzed and interpreted with statistics programme. Video records of the students' project presentations are also available. The paper will also show the interesting as well as the important results of this research in all aspects.
\end{abstract}

Keywords: project based learning, project, behaviour, ratio, proportion, percentage

\section{Introduction}

In recent years, when the amendments in Turkish educational system is examined, in particular when new primary mathematics program is investigated in terms of roles of the students and teachers, it is realized that the students are desired to be the individuals who are responsible for their own learning, thinking and interrogant, capable of building and unraveling their own problems, loving mathematics, confident in mathematics and individuals who trust team work and have self management skills (Minister of National Education, 2013).

It is very important to prefer the right and effective educational approaches for students. One of the effective teaching approaches is project based learning because students use problem solving methods, their cognitive and psychomotor skills in this approach (Kalayc1, 2008). On the other hand, the subject of ratio and proportion has an important place in the mathematics subjects in primary and seconday school level (Kayhan, 2005). Studies related to ratio, proportion and percentage are limited. Akkuş-Çıkla and Duatepe (2002) studied with preservice teachers; Duatepe, Akkuş-Çıkla and Kayhan (2005), Doğan and Çetin (2009) and Kaplan, Işleyen and Öztürk (2011), Çelik and Yetkin-Özdemir (2011) studied with elementary school teachers; Doğan and Çetin (2009) also studied with $9^{\text {th }}$ grade secondary school students in their researches about ratio and proportion.

Akkuş-Çıkla and Duatepe (2002) examined the skills of proportional reasoning and the solution strategies of preservice teachers about ratio and proportions problems. According to the result of this research, preservice teachers solved ratio and proportions problems but they did not use their definitions and did not have conceptual knowledge about these concepts.

Duatepe, Akkuş-Çıkla and Kayhan (2005) examined the solution strategies of elementary school students about proportional reasoning skills and they also investigate how the question types affected 
these strategies. 295 elementary school students from four different elementary schools participated the study and proportional reasoning test was implemented to them. At the end of the study, it was found that some of the students were thinking proportionally but they did not use any specific solution strategy.

Doğan and Çetin (2009) was conducted their studies with $7^{\text {th }}$ grade primary and $9^{\text {th }}$ grade secondary school students. They aimed to determine the participiants' misconceptions about ratio and proportion. 1085 students were participated from 20 different schools to this study. The findings showed that both groups of the students had misconceptions about ratio and proportion. The students had little information about ratio and proportion concepts' definitions. They also confused the conception of ratio with fraction, digit and division concepts. They had difficulties direct and inverse proportions problems. Misconceptions of $7^{\text {th }}$ grade students decreased but some of them lasted them at $9^{\text {th }}$ grade in secondary school.

In their study, Kaplan, Işleyen and Öztürk (2011) investigated $6^{\text {th }}$ grade students' misconception about the ratio and proportion concepts. A diagnostic test consisting of 10 questions was used to determine students' misconceptions. The results revealed that students had misconceptions in constructing ratioproportion concepts and had difficulties about proportional reasoning.

Çelik and Yetkin-Özdemir (2011) carried out the study entitled "The Relationship Between Elementary School Students' Proportional Reasoning Skills And Problem Posing Skills Involving Ratio and Proportion". 392 seventh and eighth grade students took part in the research. According to the results of analysis, there was a significant relationship between problem posing skills and proportional reasoning skills about ratio and proportion concepts.

In recent years, project based learning which includes the characteristics of various teaching methods is one of the most important educational approaches. The project based learning is an innovative approach in the process of learning and teaching. It focuses on general concepts, ideas and the principles of a discipline (Demirel, 2005, p. 67). It includes the duties for students such as researching, getting information, and introducing a product by transforming this information into a meaningful whole for resolving problems. They allow students to work on their own in a special way and construct their own information. By using authentic products the students are allowed to access the last point (Çiftçi, 2006).

With the project based learning teachers aim to let students to gain a creative learning experience. In this approach while the students are busy with their own learning experiences, teachers help their students to realize their projects. While the students are in the forefront to realize their projects, teachers are in the back ground in order to facilitate their students (Demirel, 2005, p. 69).

Studies related to project based learning in teaching-learning process in lessons become widespread in recent years. In science education, there are more studies about project based learning (ex. Seloni, 2005; Çıbık, 2006; Sert-Çıbık and Emrahoğlu, 2008; Özer and Özkan, 2013), mathematics education researches with project based learning are limited (ex. Tabuk and Özdemir, 2009; Tertemiz and Şahinkaya, 2010). In addition to them, Yllmaz (2006) used project-based learning in his study in social sciences.

Seloni's (2005) research that expresses the fact that project-based learning approach has a positive effect on the success of the students is something that supports this research.

The research of Çıbık (2006) that states the fact that project-based learning approach has a positive effect on students' logical thinking skills and their attitudes towards the lesson shows compliance with the results of this research.

Sert-Çıbık and Emrahoğlu (2008) used project-based learning in their studies in science teaching. They examined the effect of project based learning approach to the logical thinking ability of seventh grade students. The research was an experimental study and 22 students participated from each group 
(experimental and control group). Experimental group students' logical thinking ability was higher than control group students' logical thinking ability. The findings also showed that science education based project learning approach was more efficient in development of students' logical thinking ability.

Özer and Özkan (2013) examined the effect of the project based learning on scientific process ability of 37 pre-service teachers from science education department. Data obtained from the study indicated that there was no statistically significant difference between the test group and the control group in total scientific process scores. Another results showed the pre-service teachers who were taught with the project based learning method, were more successful than the pre-service teachers in control group.

Yilmaz (2006) in his study with $7^{\text {th }}$ grade students confirmed the fact that students who are taught with project-based learning increase their success and their attitudes towards the lesson is raising and their level of creativity is advancing.

In their study Tabuk and Özdemir (2009) aimed to investigate the effects of multiple intelligence approach on the $6^{\text {th }}$ grade students' mathematics achievements in project based learning. In the experimental groups mathematics lessons were carried on with project based learning, in the control group students learned mathematics with traditional methods. There were two experimental groups which had different multiple intelligences. One of them had maximum points in multiple intelligence quizzes, students that took part in other experimental group had maximum points in multiple intelligence quizzes. The findings showed that there was no statistically important effect of multiple intelligence approach in project based learning on the students' mathematics achievements. But, the students in the first experimental group were found statistically more successful according to the students in the control group, the students in the second experimental group were not found statistically more successful.

Tertemiz and Şahinkaya (2010) examined the effects of project and activity based instruction in mathematics lessons on preservice teachers' mathematics teaching efficacy beliefs. The study was an experimantal study and there were three groups (project based, activity based and control groups). The findings revelaed that project based and teacher centered instruction increased teaching efficacy of pre-servce teachers.

In this context, the main aim of this study is to investigate the effect of project based learning on $7^{\text {th }}$ grade students' mathematical success in the concepts of ratio, proportion and percentage and attitudes towards mathematics.

\section{Method}

\section{Test Subjects and their Selection}

The subjects of the experimental group of the research were chosen among the $7^{\text {th }}$ grade students of the Istanbul Eminönü Primary School. In this school $7^{\text {th }}$ graders continue their education in two separate divisions as 7-A and 7-B. In order to determine the experimental and control group of the research, a 'Mathematical Achievement Test' that includes the issues that were covered up until the time being and the issues that they will be covered during the research was applied as a pre-test to 70 students. 36 of these students were from 7-A and 34 of them were from 7-B. The average values for pretests were calculated and compared between groups. As a result of the very close average values of two classes (the Experimental group: 13.75, Control group: 13.56), and the support of the ANOVA Test analysis which was carried out in order to determine the homogeneity of the groups to this situation ( $\alpha=0.05, p=0,787>0.05), 7$ - A was chosen as an experimental group and 7-B was chosen as a control group by drawing lots. 


\section{Data Collection Instruments}

'Ratio, Proportion and Percentages' unit which will be held in the research has been divided five lower issues. These issues are respectively as follows;

1. Ratio and Proportion

2. Properties of Proportion

3. Varieties of Proportion and Proportion and the Problem Solving

4. Per cents Accounts; Per cent Rate, Per cent Proportion and Calculation of the basic issue

5. Problems with Per cent Accounts

- Accounts' related with Profit and Loss

- Discount Accounts

- Commission Accounts

- Interest Accounts

After 'Ratio, Proportion and Percentages' unit divided into sub issues, 'Project pre-study file' was prepared for each issue. Data collection instruments that were used in this study are as follows; Mathematics Achievement Test (Pre-test and Post-test), Mathematics Attitude Scale (pre and post attitude), Project Pre-Study Files, Photographs, The Project Evaluation Criteria Form, Student Observation Form, Self Evaluation Form, The Activity Assessment Form.

\section{Mathematics Achievement Test}

The questions of the Mathematics Achievement Test were elected among mathematics course books which were approved by The Ministry of Education Training and Discipline Board' and previously used questions in Secondary Education Institutions Selection Exam. At the end of the selection 30 questions was established. Regarding the evaluation of the questions, 1 point was given for all the right answers. In order to set the reliability of the test, the test was implemented to $807^{\text {th }}$ grade students in total registered to another primary school that had the same level with the research school. The data obtained have been assessed with a statistical program and alpha reliability coefficient found as 0,86 .

This achievement test was conducted as pre-test before the research and post-test at the end of the research in order to measure the difference between the successes of the students.

\section{Mathematics Attitude Scale}

In this research, 'A Condensed Mathematical Attitude Scale for Primary Mathematics Teachers' which was developed by Nazlıçiçek and Erktin in 2002 was used.

In the beginning and at the end of the research this scale was applied to experimental and control groups.

\section{Project Pre-Study Files}

There are five pre-study files prepared by the researcher with the use of various sources and Ministry of Education publications. The content of these files included the research questions related to the subjects such as Rate, Proportion and Percentage unit, besides thought provoking, interesting and router questions that allow students to learn the issues in depth.

All the project pre-study files were organized in a similar manner. The files according to their content density have different number of sections. Various tasks that will be carried out as a group, issues of research, debate questions and questions that will be answered by individuals has been given in these files to students.

The first section of the every working file includes the research issue of the week. Each group submitted what they have learned and presented them in the classroom in a class discussion of the week. The last section entitled 'What I have learned?' had the questions that are required to answer by 
the group members individually. The aim here is to see how group work affected individual learning and identify whether the subject and its properties have been learnt by the students or not and at what level they have learnt.

The parts between the first and the last section aimed to guide students to relate the properties of the subject given that week with acquiring that subjects place and implementation in everyday life. They have answered these questions as a group and if they need, they have shared the issues that they do not understand with the other groups and have reached a common point. So the issues were taken from different aspects, the mistakes or incomplete parts of a group compensated with the help of the other groups. In addition to that, teacher have always guided the groups, followed their studies closely and canalized them to the proper resources.

Project pre-study files planned to complete a file every week but more time was allocated to some files because of their content density. These files were given to the groups at the beginning of the week in order to give them the opportunity to analyze the issues, collect information and distribute the tasks of the group. However the completion of the folders was made in the class time. When they need they continue to work in the places such as library, ICT Laboratory, during dismissed class times.

\section{Student Observation Form}

'The Student Observation Form' which was taken from the literature (Erdem and Akkoyunlu, 2002) was filled by the heads of groups to assess their group mates. So whether some important behaviours such as whether group members are working in harmony with each other or not, collaboration, solidarity, sharing opinions, respecting different perspectives, expressing own opinions, were acquired by students or not was determined.

\section{Self-Evaluation Form}

All the students filled the Self-Evalution Forms which were taken from the literature (Seloni, 2005) individually. Students were asked to answer all the questions sincerely and to share all their opinions whether positive or negative.

\section{Activity Assessment Form}

These forms were filled individually by students in order to determine how the students assess their courses and their Project pre- study files. It was also aimed to understand how the work was perceived by students, useful and convenient or boring and worthless. These forms were taken from literature (Seloni, 2005) and they were changed by researcher.

\section{Project Assessment Form}

Projects that were prepared by experimental group students were assessed by the researcher according to certain criteria in the 'Project Assessment Form'. The form was taken from the Ministry of Education broadcasts and had three separate sections as planning, content and presentation of the project.

\section{Research Method}

In the research pre and post-tests experimental-control group design was used. From two groups decided in the study, for control group traditional teaching methods were used, and for experimental group project based learning method was used during the courses.

The teaching period of the each group was carried out at the same time by the researcher. 


\section{The Studies in the Experimental Group}

After the experimental group students were informed about the applications by the researcher, the project pre-study files which would guide them to search the subjects in the units were introduced. In addition to that sample projects were shown and information about project studies which were one of the parts of the study was given.

Before the study, 8 heterogeneous groups were formed which comprised 4 or 5 experimental group students. While establishing groups, chance was given to the students to be in the same group with one of their close friends that they would be happy to work with. The aim here is to increase the students' motivation and prevent the disagreement of the students while determining group members by teacher.

After forming groups, each group was asked to find a group name and a group leader. All the groups were informed about the responsibilities and duties of the group leader.

Experimental group students followed the issues with project pre- study files during 7 weeks. After three weeks that they began to study, they began their project studies by choosing a subject that they were curious about. After the students began their project studies, they learned the subjects with the help of study files, group and class discussions, on the other hand, they proceeded their project studies and they submitted a project progress report that explains how their study was proceeding at the end of each week. These reports were asked in order to let the teachers to follow their students' progress closely and guide them in the right time.

Finally experimental group students introduced their projects with 10-15 minute presentations which they had prepared according to a given pattern in a computer environment at the $7^{\text {th }}$ week which was the last week of the study. The presentations were followed by the researcher and the other group members. At the end of the study, the points that the students got from their study files in the classroom and project observation forms were added and the group score were determined.

Students had the opportunity to access every environment according to their needs during the study. Time to time, in the course time or after the course time, they continued to study in ICT laboratories or in libraries.

At the end of the study, Mathematics Achievement Test was carried out as a post-test and Mathematics Attitude Scale was used as a post-attitude scale. Besides, 'Student Observation Form', 'Self - Evaluation Form' and 'Activity Assessment Form' were used ant the results were analyzed.

\section{Studies in the Control Group}

The course was given with traditional methods to 7-B class which was the control group of the study. Mathematics Achievement Test and Mathematics Attitude Scale were also used for the control group before and after the study.

\section{The Application Process}

Rate, Proportion and Percentage unit was divided into 5 sections and a study file was prepared for each section. It was aimed to complete a study file every week. However, according to the content of the study file and the difficulty of the subjects two week time was given to complete study files.

In conclusion, the research lasted in 7 weeks and this period included the presentation of the projects.

\section{Analysis of the Data}

The data gathered through the research was analyzed by using a statistical program. It would be useful to use Shapiro Wilk Test, if the number of the data is less than 29 and if the number of the data 
is more than 29, Kolmogorov-Smirnov test should be used (Kalayc1, 2008). Since the experimental group had 36 and control group had 34 students, whether the data gathered from the samples had normal distribution or not was determined by using Kolmogorov-Smirnov test.

Since it was determined that the data showed normal distribution, while comparing the results of the pre-test and post-test, t-test was used. In order to compare pre-test and post-results between control and experimental groups, unrelated $t$-test was used $(\alpha=0.05)$. The results of pre-attitude and postattitude tests were compared in a similar way.

\section{Research Findings}

In this part, selected samples from the answers of the students that they gave to the forms during research and the data gathered before and after the research that is to search the effect of the lessons that were given through project based learning to the success were involved.

After the analysis of normal distribution of Mathematics Achievement Test (Pre-Test) and Mathematics pre-attitude Scale, pre-test, post-test, pre-attitude and post-attitude scales were assessed by using related an unrelated t-test.

According to the results of ANOVAs Test which was used in order to determine the homogeneity of the experimental and control groups (Experimental group: 13.75, Control group: 13.56, $p=0.787>$ $0.05)$, it can be said that there is not a meaningful statistical difference between experimental and control groups and it can be said that the groups are homogeneous.

Similarly, according to the results of unrelated t-test which was used in order to compare the postattitude scores of experimental and control group students (Experimental group: 77.31, Control group: $75.68, p=0,61>0,05)$, it can be said that there is not a meaningful difference between control and experimental group students' pre-study mathematical attitudes.

According to related the t-test results which was used to compare pre-test and post-test scores of the experimental group students that were shown at Table $1(p=0,000<0,05)$ a meaningful difference in favour of post-test scores can be seen between pre-test and post-test scores of experimental group students. This situation reveals the fact that there is a positive increase at the success of the experimental group students.

Table 1. The Results of related t-test that Belonged to Scores of Pre-test and Post-test Scores of Experimental Group Students

\begin{tabular}{|c|c|c|c|c|c|c|}
\hline Groups & $\mathrm{N}$ & Arithmetic Average & ss & $\mathrm{sd}$ & $\mathrm{t}$ & $\mathrm{P}$ \\
\hline Experimental Group & & & & & & \\
\hline $\begin{array}{l}\text { Pre- Test } \\
\text { Experimental Group }\end{array}$ & 36 & 13,75 & 4,56 & & & \\
\hline Post-Test & 36 & 16,47 & 5,01 & 35 & $-4,216$ & 0,000 \\
\hline
\end{tabular}

According to related the t-test results which was used to compare pre-test and post-test scores of the control group students (Pre-test: 13.56, Post-test: 14.15, $p=0,353>0,05$ ) it can be seen that there is not a meaningful difference between the pre-test and post-test scores of control group students. Because of non meaningful difference, it wasn't shown in a different table.

According to the results of the unrelated t-test (Table 2), $(\mathrm{p}=0,047<0,05)$ which was used to search whether there is a meaningful difference between the post-test scores of control and experimental group students or not, it can be seen a meaningful difference in favor of experimental group students between control and experimental group students' post-teaching success. 
Table 2. Unrelated t-test Results Belonged to Scores of Post-Test Scores of Control and Experimental Group Students

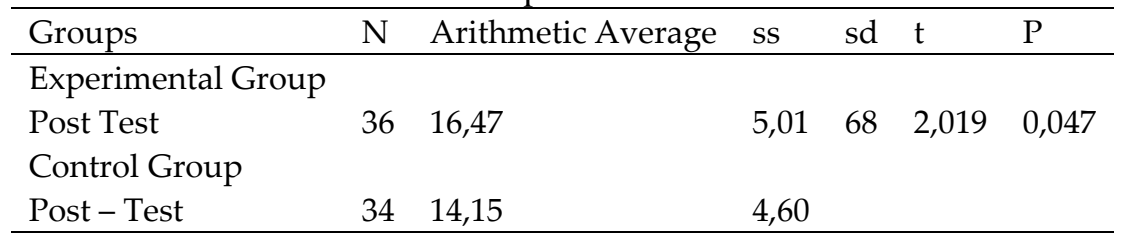

According to the results of related t-test results (Table 3); $(p=0,001<0,05)$ which was used to compare experimental group students' mathematics attitude scores before and after the study, a meaningful difference can be seen in favor of post-attitude scores of experimental group students' mathematics attitudes before and after the study. In this direction, it can be said that project based learning have effected positively the attitudes of experimental group students.

Table 3. Related t- test Results Belonged to Differentiation of Mathematics Attitudes of Experimental Group Students Before and After the Study

\begin{tabular}{lllllll}
\hline Groups & $\mathrm{N}$ & Arithmetic Average & ss & sd & t & P \\
\hline & & & & & & \\
Experimental Group Pre-Attitude & 36 & 77,31 & 14,39 & 35 & $-3,478$ & 0,001 \\
& & & & & & \\
Experimental Group Post- Attitude & 36 & 82,47 & 9,05 & & & \\
\hline
\end{tabular}

According to related t-test results (Pre-Attitude: 75,68, Post-Attitude: 77,26) which was used to compare mathematics attitude scores of control group students before and after the study, although there was an increase between mathematics attitudes of control group students before and after the study, it was seen that this differentiation was not reveal a meaningful statistical difference. Because of non meaningful difference, it wasn't shown in a different table, too.

According to unrelated t-test results (Table 4$)(\mathrm{p}=0,037<0,05)$ which was used to compare postattitudes scores of control and experimental group students, it was seen that there was a meaningful difference in favor of experience group students between two groups' mathematical attitude scores after the study.

Table 4. Unrelated t-test Results Belonged to Control and Experimental Group Students’ Post- Attitude Scores

\begin{tabular}{lllllll}
\hline Groups & N & Arithmetic Average & Ss & sd & t & P \\
& & & & & & \\
\hline Exp Group Post Att. & 36 & 82,47 & 9,05 & & & \\
Control Group Post Att. & 34 & 77,26 & 11,19 & 68 & 2,133 & 0,037 \\
\hline
\end{tabular}

Finally, the tests which were used to find out whether control and experimental group students posttest scores differentiate according to their gender and their mathematical attitudes before the study or not, were not reveal any meaningfulness.

\section{The Forms Used for the Experimental Groups}

\section{Self - Evaluation Form}

This form was given to every student after the project presentations and they are asked to fill out this form sincerely. The aim of this form to gather positive and negative opinions of the students about the project study which was one of the parts of the study. The selected samples of the answers for the open-ended questions of the form are as in the following: 
Question 1: What is the most important information that you acquired from the Project studies?

'That we use Rate and Proportion everywhere' Cansu, STORM

'The most important information is doing something with our own minds and they are useful things for other people' Cansu, SAPROFITS

'I learned to work in a group' Metin Bora, MEN IN BLACK

'Team work and team spirit. Working with all my teammates like a single body' Hasan, RAINBOW

Question 2: How can you use this information that you acquired during the project study?

'We can use it while we are looking at the prices at the supermarkets' Aykut, NOBELYON 'In my lessons, in my life, in the fields that I work' Ümmühan, FANTASTIC FOUR

'We have already used this information in our daily life. For example the proportion of the students who succeed in the university entrance examination and who cannot' Hande, STORM

'I can use it in my life, because I generally use rate and proportion in calculations' Orhun, RAINBOW

Question 3: I have made the activities related to project studies caressively, because;

'I have both my close friends and there are amazing subjects' Ramazan Can, FRESH BRAINS

'We worked together with our friends' Burakcan, MEN IN BLACK

'Our group is good, we made everything together' Viktor, SAPROFITS

'Yes, we both laugh and got angry. I loved because we made a group work except one person' Gözde, NOBELYON

'Our subjects were enjoyable. We were making a book and it was our work of art. We wrote everything ourselves. It was our knowledge, for this reason I did it caressively, Hande STORM

Question 4: I got bored during the project studies, because;

'I got bored sometimes because some friends did not fully complete their duties' Ümmühan FANTASTIC FOUR

'Sometimes, I got bored, I was afraid that we fail or ruin the whole project' Merve STORM 'Group members are not working hard; they did not do their best' Bahtınur MEN IN BLACK

'Yes, sometimes I got bored, because it is boring to stress a thought or a problem' Meltem LOONEY TUNES

Question 5: I was good at project works, because;

'I was good at project tasks, I tried hard to finish my project, I did my best to accomplish it' Yasemin, STORM

'I was good at some subjects, for example I produce ideas and thoughts' Meltem, LOONEY TUNES

'I was a group leader, managed everyone' Sevcan, E. SAPROFITS

'I care about my work; I took it serious and did it properly' Orhun, RAINBOW

Question 6: I was not good at my project work. Because,

'I was not good at much at my project work' Furkan, SAPROFITS

'I was not good at calculations; that is I could not do it properly' Meltem, LOONEY TUNES

'I could not say I was successful because I was very talkative' Y. Emre, FRESH BRAINS

'I was not good at preparing my own question. I received help from others' Burakcan, MEN IN BLACK 
Question 7: I Fell like I am a scientist in my project studies and in activities that I made, because,

'I felt like I had great responsibility' Karina, NOBELYON

'I did not feel' Y. Emre, FRESH BRAINS

'Yes, sometimes it happens, I suppose I was a scientist when I made these activities and dealt with something' Vahdet, STORM

'I produced a project and I felt like a scientist' Ahmet Ufuk, LOONEY TUNES

'We made up a formula and it could be helpful for the people' Sevcan Eylem, SAPROFITS

'I focused on a subject and realized it just like a scientist' Hasan, RAINBOW

\section{Activity Assessment Form}

This form was filled by every student individually in order to determine how the students evaluate the courses with 'Project pre-study Files', how they evaluate the activities in these files, whether they got bored from making any research or not and whether they perceived these activities useful to themselves or not.

Question 1: Do you think having a mathematics course with study files and making projects was useful to you?

'Yes, it was. We became enlighten; it was more pleasure to have lessons like this. We got surprised at first, this is the firs time that such a thing happened' Zeynep, FANTASTIC FOUR 'Yes, because we wrote the things that we understood on paper so that we deeply understood by writing it second time and it became a repetition' Hasan, RAINBOW

'Yes, because the lessons became more enjoyable, I learnt useful knowledge' Y. Emre, FRESH BRAINS

'Yes, because we learnt to work in a group' M. Bora, MEN IN BLACK

'Sometimes it was useful and sometimes it was harmful, because I did not understand some subjects and I could not study about the subjects that I did not understand, but working on new ideas was useful' Meltem, LOONEY TUNES

I was not quite useful, because we could not learn the lessons completely; we could not listen to the subjects from the teacher' Sevcan Eylem, SAPROFITS

Question 2: What are the challenges that you faced during the course and the deficiencies that you saw?

'There were some difficulties, but we handled the by cooperating as a group' M. Bora, MEN IN BLACK

'Preparing a survey was the most difficult thing during the unit, because we could not decide about the questions' Kadir, RAINBOW

'There was not much, only we had a trouble on composite proportion' Y. Emre, FRESH BRAINS

'We struggled a lot on the questions that we could not make, we struggled a lot on project studies and we wanted help from the teacher' Aykut, NOBELYON

Question 3: How do you evaluate this project study?

'I think it was a good study, we all understood that we can be successful' Merve, STORM

'It was good but having a traditional course is better' Şeyma, FANTASTIC FOUR

'I evaluate this project study as good because I became more responsible' Hasan, FRESH BRAINS

'In fact it was fun but there were some subjects that we could not understand; besides we always had to think in conclusion our brain got tired and we could not think the lessons' Meltem, LOONEY TUNES 
'I think that with the help of this project study our skills like, cooperation; solidarity, researching and learning were developed' Orhun, RAINBOW

Question 4: Do you think that project studies should be done only in Mathematics lessons or project studies should be done in other lessons? Why?

'It should be done in all lessons, because we get along well as a group' Cemal, SAPROFITS

'It should be done in all lessons so that everyone could get used to each other and we could have a better understanding' Mustafa, RAINBOW

'I want my teachers to use project studies in ever lesson, because we became more responsible' Caner, FRESH BRAINS

'In all lessons because it was more efficient and more enjoyable' Zülal, LOONEY TUNES

'If it was done in different lessons, we could have faced with more challenges because we could forget one while working the other lesson' Karina, NOBELYON

'I think project studies should be used in Mathematics lessons; that is, how could we make new things in other lessons? Besides we can also make projects in Technology lessons' Hande, STORM

Question 5: Which one is more efficient? The teacher gives the lesson or you reach the knowledge by yourselves with the help of group work?

'I think both were efficient' Vahdet, STORM

'All of them were efficient, we both learnt in all ways' Nevin, FANTASTIC FOUR

'Of course, if the teacher tells us, it will be cool because in group works some students do not work, but when the teacher gives the lesson, we understand everything' Karina, NOBELYON

'If the teacher gives the lesson, it will be better because we have a better understanding, in group work we do not understand much' İpek, LOONEY TUNES

'Reaching the information by ourselves wit the help of group work' Burakcan, MEN IN BLACK

'Both would be efficient but I would rather teacher to give the lessons because the teacher repeats the parts that we cannot understand' Orhun, RAINBOW

\section{Discussion, conclusion and suggestions}

\section{Discussion and conclusion}

As a result of this research, it is observed that project-based learning is more effective than traditional teaching methods on students' mathematical achievements and having a positive attitude against lesson. Besides, it is seen that project - based learning is more effective than traditional teaching methods on teaching and acquiring the target acquisitions of the rate, proportion and percentage unit. The results from the answers that experimental group students gave to the forms that were applied to them are as follows:

1. Using project-based learning approach inspires occurring a creative classroom atmosphere; students generally perceive project work as enjoyable and entertaining.

2. Students express that they learnt many things such as taking responsibility, cooperation and team work. Reaching the information on their own, learning by themselves with the help of information that they reach on their own, making a product with the help of a team develop their communication skills and help students to rely on themselves.

3. The group work under the guidance of the teacher, cooperation among groups and class discussions help to deal with the subjects deeply so that students can contribute each other's learning.

4. While Students who enjoyed project works which are one of the parts of Project-based learning, generally express that they have a healthy communication in the group and everyone completed the tasks that they were responsible for, the other students who got 
bored from the studies express that they had problems with others in the group or they express the fact that learning by themselves was boring and challenging.

In conclusion, this study shows the fact that mostly teacher-centered mathematical classes can be taught with project-based learning approach successfully.

In literature most of the studies (Tabuk and Özdemir, 2009; Tertemiz and Şahinkaya, 2010) that analyse the effect of project-based learning approach on the achievement in the mathematics lessons and attitude towards lessons is supporting the findings of this research related to achievement and attitude.

\section{Suggestions}

These suggestions can be offered to teachers and researchers who think to use this approach after the results of this research:

1. A teacher who thinks to use project-based learning approach should know the weaknesses and strengthens of this approach and should plan carefully by considering the characteristics and density of the unit or the subjects that he or she will teach.

2. Teacher should introduce the project-based learning approach to his or her students properly and should tell his or her students that project based learning is an enjoyable and useful approach that helps them to teach learning to learn and help each other to learn.

3. You should be very careful while forming the groups and should be careful to let students to be in a group that he or she can work effectively in order to get the desired output. Besides we should try to combine students that can work together and get along well. In this research the idea which was used by the researcher and can be suggested to other researchers who thinks to use group work that a student should be in a group at least together with one of his or her friends whom he or she likes to work together was perceived very effective and seen that this idea prevents the disagreement of the students while forming groups.

4. This study is limited with 'Rate, Proportion and percentage' unit. New research can be carried out with the other units in the curriculum especially with geometry subjects.

5. The research related with the effect of this approach to success should not be limited to primary schools and can be used in secondary schools and in universities.

6. One of the main goals of the new primary curriculum is learning to learn coincide with the principles of project-based learning. For that reason making this approach more understandable and applicable helps us to understand ad reach the goals of the new primary curriculum.

7. In project studies it is inevitable to use computers so we need to give courses that help students to use computers.

8. The effect of project-based learning approach and project studies to mathematics success and attitude displayed in this research. The effect of this approach to other lessons success, attitude and retrieval or to holistic thinking, problem solving and thinking and learning styles can be searched.

9. In this research the effect of having 'Rate, Proportion and percentage' unit with project basedlearning approach to mathematics success was compared with traditional approaches. Similar studies in order to compare project -based learning approach with other approaches can also be carried out.

10. In addition that, for the sake of efficiency and studies the ideal number of students in one classroom should be between 20-25.

\section{References}

Akkuş-Çıkla O., and Duatepe, A., (2002). İlköğretim matematik öğretmenliği öğretmen adaylarının orantısal akıl yürütme becerileri üzerine niteliksel bir çalışma, Hacettepe Üniversitesi Ĕ̆itim Fakültesi Dergisi, 23, 32-41.

Çelik, A., and Özdemir, E. Y., (2011). İlköğretim öğrencilerinin orantısal akıl yürütme becerileri ile oran-orantı problemi kurma becerileri arasındaki ilişki. Pamukkale Üniversitesi Ĕ̆itim Fakültesi Dergisi, 30(1), 1-11. 
Çıbık, S. A., (2006). The effect of project based learning approach to students' logical thinking skills and attitudes in science lesson. Unpublished master's thesis, Çukurova University, Social Sciences Institute, Adana.

Çiftçi, S., (2006). The effect of project-based learning to students academic risk level, to problem solving skills and attitudes in teaching social sciences lesson. Unpublished doctoral dissertation, Selçuk University, Social Sciences Institute, Konya.

Demirel, Ö., (2005). New Approaches in Education. Ankara: Pegem A.

Doğan, A., and Çetin, İ., (2009). Doğru ve ters oranti konusundaki 7. ve 9. sinif öğrencilerinin kavram yanilgilari. Uşak Üniversitesi Sosyal Bilimler Dergisi, 2(2), 118-128.

Duatepe, A., Akkuş-Çıkla O., and Kayhan, M., (2005). Orantısal akıl yürütme gerektiren sorularda öğrencilerin kullandıkları çözüm stratejilerinin soru türlerine göre değişiminin incelenmesi. Hacettepe Üniversitesi Ĕ̆itim Fakültesi Dergisi, $23,73-82$.

Erdem, M., and Akkoyunlu, B., (2002). İlköğretim sosyal bilgiler dersi kapsamında beşinci sınıf öğrencileriyle yürütülen ekiple proje tabanlı öğrenme üzerine bir çalışma. İlköğretim Online, 1(1), 2-11.

Kalaycı, N., (2008). Yükseköğretimde proje tabanlı öğrenmeye ilişkin bir uygulama projeyi yöneten öğrenciler açısından analiz. Eğitim ve Bilim, 33(147), 85-105.

Kalaycı, Ş., (2009). Applied SPSS multivariate statistical techniques. Fourth Edition, Asil Press: Ankara.

Kaplan, A., İşleyen, T., and Öztürk, M., (2011). 6. sınıf oran orantı konusundaki kavram yanılgıları. Kastamonu Ĕ̆itim Dergisi, 19(3), 953-968.

Kayhan, M., (2005). 6. ve 7. sını öğrencilerinin oran-orantı konusuna yönelik çözüm stratejilerinin; sinıf düzeyine, cinsiyete ve soru tipine göre değişiminin incelenmesi, Unpublished master's thesis, Hacettepe University, Ankara.

Ministry of National Education [MoNE]., (2013). Ortaokul matematik dersi öğretim programı 5, 6, 7 ve 8. sınıflar: Öğretim programı ve kılavuzu. Ankara, Turkey: MoNE

Nazlıçiçek, N., Erktin, E., (2002). İlköğretim Matematik Öğretmenleri İçin Kısaltılmış Matematik Tutum Ölçeği. 5. Ulusal Fen Bilimleri ve Matematik Eğitimi Kongresi, 16-18 Eylül, ODTÜ, Ankara.

Özer, D. Z., and Özkan, M., (2013). The effect of project based learning method on science process skills of prospective teachers of science education in biology lessons. International Online Journal of Educational Sciences, 5(3), 635-645.

Seloni, R. Ş., (2005). Removing misconceptions by using project based learning approach in teaching science lessons. Unpublished master's thesis, Marmara University Educational Sciences Institute, Istanbul.

Sert-Çıbık, A. and Emrahoğlu, N., (2008). Proje tabanli öğrenme yaklaşiminin fen bilgisi dersinde öğrencilerin mantiksal düşünme becerilerinin gelişimine etkisi. Ç.Ü. Sosyal Bilimler Enstitüsü Dergisi, 17(2), 51-66.

Tabuk, M. and Özdemir, A. Ş., (2009). The effects of multiple intelligence approach in project based learning on mathematics achievement. International Online Journal of Educational Sciences, 1(1), 177-195.

Tertemiz, N., and Şahinkaya, N., (2010). Proje ve etkinlik destekli ogretimin sinif ogretmeni adaylarinin matematik ogretimine yonelik yeterlik inanclarina etkisi. Abant Izzet Baysal Universitesi Dergisi, 10(1), 87-98.

Y1lmaz, O., (2006). The effect of project based learning approach to learners academic success, creativity and attitude in primary 7 th grade social sciences. Unpublished master's thesis, Zonguldak Karaelmas University, Social Sciences Institute, Zonguldak. 